\title{
Strategi Komunikasi Guru Terhadap Siswa Berprestasi
}

\author{
Bobby Walanda Lungido, Yugih Setyanto \\ Bobby.915160058@stu.untar.ac.id,yugihs@fikom.untar.ac.id
}

Fakultas Ilmu Komunikasi Universitas Tarumanagara

\begin{abstract}
Basically, humans want to get recognition from others. One way is to score achievements so that they can be recognized by others. For high school students, the teacher's role in helping them score achievements is very important, because the teacher will be the first to introduce, teach and guide their students to understand, understand and score achievements. The method used in this study is the interpersonal communication approach that is centered on interpersonal attraction, strung carrot strategy and sword depending on the teacher's strategy to support student achievement. This research uses a qualitative approach. While the technique of collecting data using interviews, observation and documentation. The results showed that interpersonal attraction between teacher and students and the provision of rewards as an implementation of the strung carrot strategy can provide more motivation for students in teaching and learning activities to score achievements, while punishment can motivate learning to avoid punishment and not to score achievements.
\end{abstract}

Keywords: achievement, interpersonal communication, punishment, reward.

\begin{abstract}
Abstrak
Pada dasarnya manusia ingin mendapatkan pengakuan dari orang lain. Salah satu caranya adalah dengan mencetak prestasi agar dapat diakui oleh orang lain. Bagi siswa SMA, peran guru dalam membantu mereka mencetak prestasi sangatlah penting, karena guru akan menjadi orang pertama yang memperkenalkan, mengajar dan membimbing siswanya untuk mengerti, memahami dan mencetak prestasi. Metode yang digunakan dalam penelitian ini adalah dengan pendekatan komunikasi interpersonal yang berpusat pada atraksi interpersonal, strategi wortel teruntai dan pedang tergantung dalam strategi guru untuk menunjang prestasi siswa. Penelitian ini menggunakan pendekatan kualitatif. Sementara teknik pengumpulan data dengan menggunakan wawancara, observasi dan dokumentasi. Hasil penelitian menunjukkan dengan adanya atraksi interpersonal antara guru dan murid serta pemberian reward sebagai implementasi dari strategi wortel teruntai dapat memberikan motivasi yang lebih bagi siswa dalam kegiatan belajar mengajar untuk mencetak prestasi, sedangkan punishment dapat memberi motivasi belajar untuk menghindari hukuman dan bukan untuk mencetak prestasi.
\end{abstract}

Kata Kunci: komunikasi interpersonal, prestasi, punishment, reward.

\section{Pendahuluan}

Sifat dasar manusia adalah ingin mendapatkan pengakuan dari orang lain sebagai makhluk sosial. Semua orang ingin memiliki prestasi, tidak terkecuali siswa di sekolah. Banyak siswa berusaha untuk mendapatkan prestasi di sekolahnya. Menurut Harjati (2008), prestasi adalah hasil usaha yang dilakukan dan menghasilkan perubahan yang dinyatakan dalam bentuk simbol untuk menunjukkan kemampuan yang dapat dicapai dalam hasil kerja dengan kurun waktu tertentu. 
Dalam Undang-Undang Republik Indonesia No. 14 Tahun 2005 tentang guru dan dosen, guru adalah pendidik profesional dengan tugas utama mendidik, mengajar, membimbing, mengarahkan, melatih, menilai dan mengevaluasi peserta didik pada pendidikan usia dini jalur pendidikan formal, pendidikan dasar, dan pendidikan menengah.

Menurut Muhibbin Syah (2008) dalam bukunya "Psikologi Pendidikan", prestasi belajar dipengaruhi oleh tiga faktor, yaitu faktor internal, faktor eksternal dan faktor pendekatan belajar. Faktor internal berarti dipengaruhi dari dirinya sendiri, sedangkan faktor eksternal meliputi lingkungan sosial (orang tua dan keluarga, sekolah dan masyarakat sekitarnya) dan non sosial (fasilitas belajar, tempat belajar, keadaan dan waktu belajar).

Dengan menggunakan komunikasi interpersonal untuk menarik perhatian siswa terhadap guru maupun pelajaran dan melibatkan strategi kendali komunikasi yaitu reward dan punishment untuk menunjang prestasi. Azeharie dkk (2015) menyatakan, komunikasi yang diterapkan guru dengan mendekatkan diri dengan siswanya akan menciptakan komunikasi interpersonal yang sangat baik dan akan terjalin atraksi interpersonal sehingga menjadikan komunikasi interpersonal yang lebih efektif.

Rumusan masalah dalam penelitian ini adalah, bagaimana strategi kendali komunikasi antara guru dengan siswa berprestasi di sekolah SMA Ricci I Jakarta. Rumusan masalah tersebut dibuat dengan tujuan untuk mengetahui peran komunikasi interpersonal dan strategi kendali komunikasi pemberian reward ataupun punishment dalam kegiatan belajar mengajar untuk menunjang prestasi murid.

\section{Metode Penelitian}

Peneliti menggunakan metode penelitian kualitatif untuk meneliti strategi kendali komunikasi guru terhadap siswa berprestasi di SMA Ricci I Jakarta. Menurut Kriyantono (2009), penting untuk menentukan jenis penelitian dan menyesuaikan pola permasalahan yang ingin dibahas. Penelitian harus dilakukan dengan detail tentang suatu objek tertentu dengan mendalam dan menyeluruh lalu dicari keterkaitan satu faktor dengan yang lainnya.

Peneliti menggunakan pendekatan kualitatif untuk dapat mengetahui lebih dalam mengenai bagaimana komunikasi guru dengan murid yang memiliki prestasi. Metode penelitian kualitatif adalah metode yang biasa digunakan terhadap penelitian yang menggunakan objek yang sifatnya alamiah, dimana peneliti sebagai kunci instrumen, dengan menggunakan cara pengumpulan data triangulasi, lalu dianalisis dengan induktif dan hasil penelitian yang lebih ditekankan (dipertegas) daripada digeneralisasi (Sugiyono, 2016).

Teknik pengumpulan data menggunakan observasi, wawancara dan dokumentasi. Observasi atau pengamatan adalah kegiatan keseharian manusia dengan menggunakan panca indra mata sebagai alat bantu utamanya selain panca indra lainnya seperti telinga, penciuman, mulut dan kulit. Observasi adalah kemampuan seseorang untuk menggunakan pengamatannya melalui hasil kerja panca indra mata serta dibantu dengan panca indra lainnya (Bungin, 2011).

Salah satu bentuk pengumpulan data yang paling sering digunakan adalah wawancara. Menurut Setyadin (2005, dalam Gunawan, 2014), wawancara adalah suatu percakapan yang diarahkan pada suatu masalah tertentu dan merupakan proses tanya jawab lisan dimana dua orang atau lebih berhadapan secara fisik. Menurut 
Sugiyono (2007, dalam Gunawan, 2014), dokumen merupakan catatan peristiwa yang sudah berlalu yang berbentuk tulisan, gambar, atau karya monumental. Peneliti juga menggunakan metode studi dokumen agar hasil penelitian ini dapat lebih dipercaya jika didukung oleh beberapa dokumen.

\section{Hasil Temuan dan Diskusi}

Dengan adanya standar yang ditetapkan sebagai standar operasional prosedur (SOP) bagi guru yang mengajar di sekolah SMA Ricci I, setiap guru harus bisa mengendalikan kelas yang berarti harus bisa menarik perhatian murid untuk mau belajar dan memperhatikan. Salah satu caranya adalah dengan membuat ketertarikan interpersonal (atraksi interpersonal) antara guru dan murid.

Cara mengajar yang digunakan oleh sebagian guru di sekolah SMA Ricci I adalah dengan cara tarik ulur dalam kegiatan belajar mengajar agar siswa tidak merasa bosan, memberikan kesempatan bagi mereka untuk mengeksplorasi sesuatu yang ingin mereka pelajari dan membahasnya di kelas saat kegiatan belajar mengajar (konsep kurikulum 2013).

Banyak siswa yang mendapatkan reward dari sekolah saat mereka berhasil meraih prestasi baik dalam bidang akademik maupun non akademik. Namun, reward yang diberikan hanya dapat memotivasi sebagian murid yang mempunyai kapasitas lebih dalam bidang tertentu, sehingga kurang memotivasi siswa yang kurang dalam bidang akademik maupun non akademik (siswa rata-rata).

Bagi guru pengampu mata pelajaran, memberi reward hanyalah sebatas nilai lebih atau nilai tambah karena hal itulah yang dicari oleh siswa siswi di sekolah. Siswa akan merasa lebih semangat belajar jika ada reward yang diiming-imingi (terutama berupa uang). Setelah siswa meraih prestasi dan menerima berbagai macam reward dari sekolahnya, mereka akan merasa lebih termotivasi untuk mendapat prestasi dan memperoleh reward lainnya. Dengan adanya reward, mereka jadi semakin semangat belajar. Mereka mendapatkan hadiah, baik hadiah dari hasil lomba maupun hadiah dari sekolah karena telah mengharumkan nama baik sekolahnya.

Sekolah SMA Ricci I tidak memberlakukan punishment yang berat bagi siswa siswi yang mendapat nilai kurang dari rata-rata, mereka hanya memberi punishment berupa remedial, tugas tambahan atau pelajaran tambahan. Dengan ketiadaan punishment yang berat, di sekolah ini tidak memberlakukan punishment yang berpotensi membuat siswanya merasa "down" saat mendapat nilai yang kurang memuaskan (menyebutkan nilai yang tidak lulus di depan umum), meskipun hal itu ditujukan untuk memotivasi agar menjadi lebih giat belajar dan tidak remedial lagi. Pihak sekolah hanya memberi punishment berupa remedial atau tugas. Punishment memiliki peran dalam memotivasi belajar agar tidak mendapatkan hukuman. Tetapi bagi sebagian murid punishment itu tidak diperlukan. Jika diberlakukan, punishment siswa cenderung takut dan tertekan sehingga membuat nilai semakin turun.

Salah satu hal penting bagi seorang guru untuk menunjang muridnya agar dapat menjadi siswa berprestasi adalah dengan membuat murid memperhatikan saat guru sedang menjelaskan. Tetapi mendapatkan perhatian/attraction bukanlah hal yang mudah, terutama dalam pelajaran biologi (pelajaran yang dibahas dalam penelitian ini).

Cara yang biasa digunakan oleh Riki (guru biologi) di sekolah ini agar siswasiswinya memperhatikan saat kegiatan belajar mengajar berlangsung, yaitu dengan cara tarik ulur siswa agar tertarik dengan pelajarannya. Dengan gaya yang seru dan 
cara tarik ulur itu dia berhasil menguasai kelas dan menerangkan kepada muridmuridnya. Dengan gaya mengajar yang diterapkan Riki ini, tiga siswa (Albert, Kinan, dan Philip) menjadi tertarik dan bahkan berhasil menjadi juara 1 dalam perlombaan yang diadakan oleh Fakultas Kedokteran Universitas Atma Jaya Tingkat SMA.

Ketiga siswa terbilang cukup dekat dengan Riki karena telah beberapa kali mengikuti lomba dan didampingi oleh Riki. Riki juga mengenal mereka lebih personal (ada atraksi interpersonal antara keduanya). Mereka merasa pelajaran Biologi menarik dan Riki sebagai guru pengampu pelajaran Biologi dikenal asyik dan tidak membosankan, sehingga faktor tersebut mendukung siswa untuk lebih menyukai pelajaran.

Dari temuan peneliti saat melakukan wawancara, peneliti yakin atraksi interpersonal antara guru dan murid sangat membantu dalam menunjang prestasi siswa/siswi. Tanpa adanya daya tarik murid kepada guru maka kemungkinan murid dalam memperhatikan saat gurunya mengajar dan menjelaskan akan berkurang. Saat murid kurang memperhatikan gurunya saat mengajar maka murid tersebut tidak akan paham sehingga nilainya akan menurun dan dia tidak akan bisa mendapat prestasi seperti yang diharapkan.

Sama seperti sekolah lainnya, SMA Ricci I juga memiliki cara untuk memacu siswa untuk mencetak prestasi. Dengan pemberian reward dalam menunjang prestasi siswa terbilang cukup ampuh. Dengan adanya iming-iming mendapat reward, siswa akan menjadi lebih semangat dalam belajar, baik dalam bidang akademik maupun non akademik. Selain itu, siswa siswi yang memenangkan perlombaan akan diberikan ucapan selamat di depan seluruh peserta didik dan guru-guru saat upacara bendera ataupun apel pagi yang menjadikan semua murid berprestasi mempunyai prestige tersendiri.

Bagi siswa yang belajar di SMA Ricci I terutama siswa berprestasi seperti Albert, Kinan dan Philip, reward sangat membantu mereka dalam menunjang prestasi. Meskipun sudah pernah mendapatkan reward karena berhasil mengharumkan nama sekolah, mereka juga ingin mempertahankan prestasi mereka untuk prestige dan mendapatkan reward lainnya. Dapat disimpulkan bagi siswa berprestasi, pemberian reward dapat menunjang prestasi mereka.

Strategi pedang tergantung (punishment) biasanya digunakan sebagai ganjaran yang diterima seseorang karena gagal/lalai dalam mencapai target yang telah ditentukan. Setiap sekolah pasti mempunyai target (nilai minimum standar kelulusan mata pelajaran) yang harus dicapai, dan jika tidak mencapai target tersebut siswa akan menerima hukuman berupa pelajaran tambahan, remedial atau tugas tambahan.

Punishment dapat memberikan motivasi bagi siswa-siswi berprestasi tapi akan lebih memotivasi siswa pada umumnya. Punishment dapat menambah motivasi belajar siswa untuk tidak mendapat remedial, tugas tambahan, ataupun rasa malu karena tidak mencapai nilai minimal yang ditentukan.

Bagi siswa berprestasi seperti Albert, Kinan dan Philip, punishment memiliki peran untuk memotivasi mereka dalam belajar agar tidak terkena punishment. Namun mereka tidak setuju dengan anggapan punishment dapat memotivasi mereka untuk mencetak prestasi, karena dengan adanya punishment mereka akan lebih mudah tertekan. Bagi mereka, punishment bisa membantu untuk mencapai suatu standar, tetapi tidak dapat membantu mereka mencetak prestasi. Dapat disimpulkan, bahwa punishment tidak dapat memotivasi siswa berprestasi untuk mempertahankan atau mencetak prestasi-prestasi baru. 


\section{Simpulan}

Dalam kegiatan belajar mengajar, atraksi interpersonal dalam komunikasi interpersonal yang dilakukan oleh guru dan murid sangat penting karena dapat mempermudah guru dalam memberikan materi kepada murid-muridnya. Dengan adanya atraksi interpersonal dan ditambah dengan pemberian reward dapat membantu siswa lebih termotivasi untuk belajar dan mencetak prestasi. Berbeda dengan punishment, hanya mampu membantu mencapai suatu target tetapi tidak secara maksimal, punishment tidak dapat diterapkan untuk mencetak prestasi tetapi dapat digunakan untuk mencapai suatu target minimal.

\section{Ucapan Terima Kasih}

Penelitian ini dapat terlaksana karena bantuan dan dukungan dari banyak pihak. Oleh sebab itu, peneliti ingin menyampaikan rasa terima kasih yang sebesarbesarnya kepada keluarga dan semua pihak yang ikut terlibat dan telah membantu peneliti selama proses penelitian ini berlangsung.

\section{Daftar Pustaka}

Budyatna, M. (2011). Teori Komunikasi Antarpribadi. Jakarta: Kencana.

Bungin, B. (2007). Penelitian Kualitatif: Komunikasi, Ekonomi, Kebijakan Publik, dan Ilmu Sosial Lainnya. Jakarta: Kencana.

Bungin, B. (2007). Penelitian Kualitatif: omunikasi, Ekonomi, Kebijakan Publik, dan Ilmu Sosial Lainnya. Jakarta: Prenada Media Group.

Dariyo, S. \&. (2016). Hubungan Antara Persepsi Siswa Terhadap Keterlibatan Orangtua Dan Motivasi Belajar Dengan Prestasi Belajar Matematika Pada Siswa Sekolah Dasar (Studi di Kota Pangkalpinang, Bangka Belitung). Jurnal Psikogenesis.

DeVito, J. A. (2013). The Interpersonal Communication Book. New York: Pearson Education, Inc.

Ghullam Hamdu, L. A. (2011). PENGARUH MOTIVASI BELAJAR SISWA TERHADAP PRESTASI BELAJAR IPA. Jurnal Penelitian Pendidikan, 13, 81-86.

Gunawan, I. (2014). Metode Penelitian Kualitatif: Teori \& Praktik. Jakarta: Bumi Aksara.

Harjati. (2008). Psikologi Belajar. Jakarta: PT. Rineka Cipta.

Kriyantono, R. (2006). Teknik Praktis Riset Komunikasi Disertai Contoh Praktis Riset Media, Public Relations, Advertising, Komunikasi Organisasi, Komunikasi Pemasaran. Jakarta: Kencana.

Liliweri, A. (2011). Komunikasi Serba Ada Serba Makna. Jakarta: Kencana.

Maesaroh, S. (2013). PERANAN METODE PEMBELAJARAN TERHADAP MINAT DAN PRESTASI BELAJAR PENDIDIKAN AGAMA ISLAM . Jurnal Kependidikan.

Morissan. (2008). Manajemen Public Relations: Strategi Menjadi Humas Profesional. Jakarta: Kencana. 
Ngalimun. (2016). Ilmu Komunikasi Adalah Sebuah Pengantar Praktis. Yogyakarta: Pustaka Baru Press.

Rahayu, K. (2017). Upaya Meningkatkan Prestasi Belajar Matematika Materi Pecahan. Indonesian Journal on Education and Research, 2, 153-157.

Syah, Muhibbin. (2008). Psikologi Pendidikan dengan Pendekatan Baru. Bandung: PT Remaja Rosda Karya.

Sudhana, N. R. (2013). Hubungan Antara Komunikasi Interpersonal Pasutri. Jurnal Psikologi Udayana, 1, 22-31.

Sugiyono. (2016). Metode Penelitian Kuantitatif, Kualitatif, dam R\&D. Bandung: Alfabeta.

Azeharie Suzy, N. K. (2015). Pola Komunikasi Antarpribadi antara Guru dan Siswa di Panti Sosial Taman Penitipan Anak "Melati" Bengkulu. Jurnal Pekommas, 213-224.

Yin, R. K. (2014). Studi Kasus: Desain \& Metode. Jakarta: Rajawali Pers. 